\title{
Correction: The role of LPA and YAP signaling in long-term migration of human ovarian cancer cells
}

Hui Cai ${ }^{1,2}$ and $\operatorname{Yan} \mathrm{Xu}^{2^{*}}$

\section{Correction}

In the original paper published [1], there is a mistake in Figure 4. Figure 4D and Figure 4E are the same, but Figure 4E should have been different (the figures show two different cell lines). Figure 1 in this correction article is the correct version of Figure 4 from the original article [1]. The figure legend does not need to be changed.

\footnotetext{
*Correspondence: xu2@iupui.edu

${ }^{2}$ Department of Obstetrics and Gynecology, Indiana University School of Medicine, 975 W. Walnut St. IB355A, Indianapolis, IN 46202, USA

Full list of author information is available at the end of the article
} 


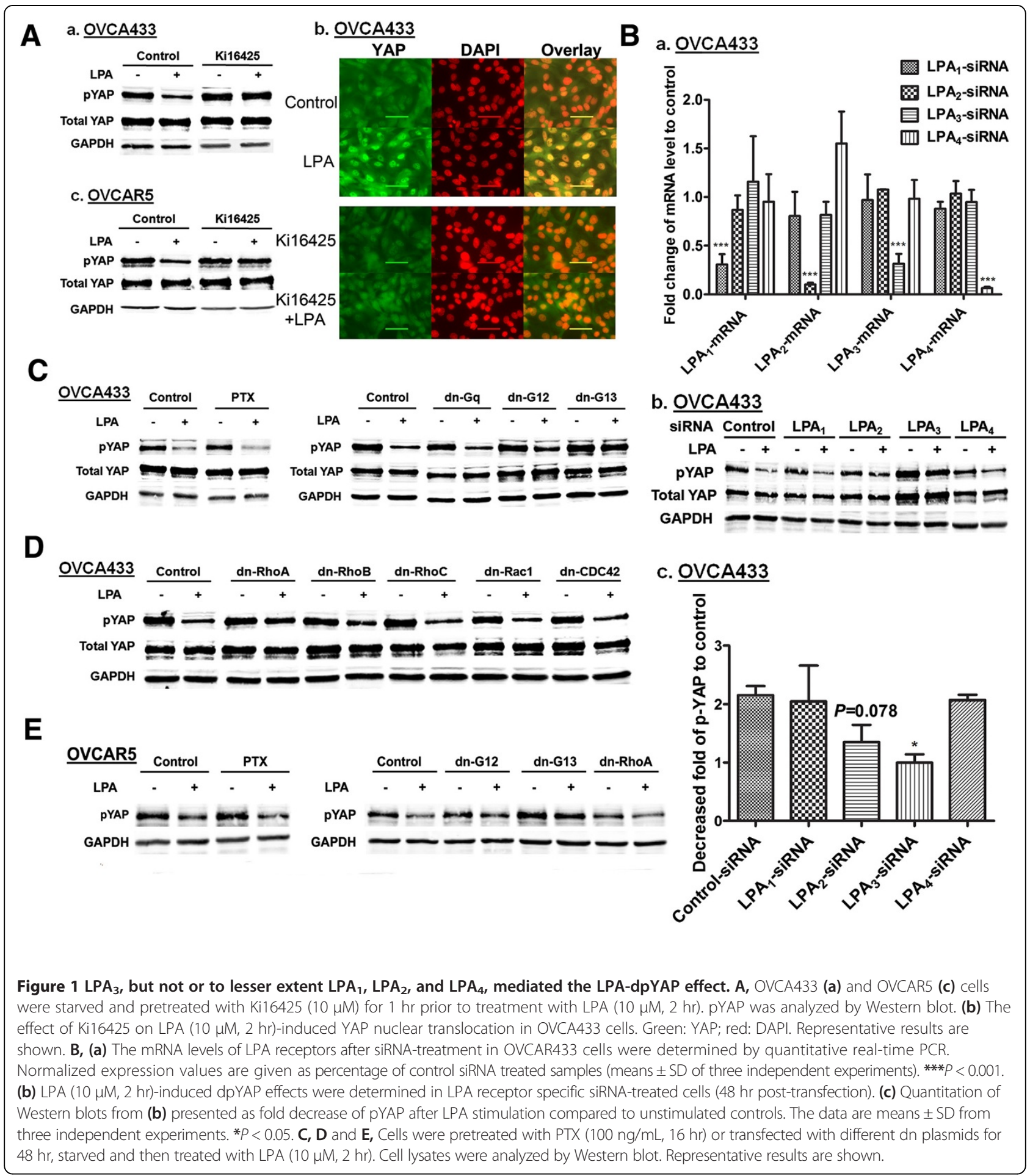

\section{Author details}

${ }^{1}$ First Affiliated Hospital, Xi'an Jiaotong University, Xi'an, China. ${ }^{2}$ Department of Obstetrics and Gynecology, Indiana University School of Medicine, 975 W. Walnut St. IB355A, Indianapolis, IN 46202, USA.

Received: 4 December 2013 Accepted: 4 December 2013 Published: 13 December 2013

\section{References}

1. Cai $H, X U$ Y: The role of LPA and YAP signaling in long-term migration of human ovarian cancer cells. Cell Communication and Signaling 2013, 11:31. doi:10.1186/1478-811X-11-31. PMID: 23618389.

Cite this article as: Cai and Xu: Correction: The role of LPA and YAP signaling in long-term migration of human ovarian cancer cells. Cell Communication and Signaling 2013 11:92. 